Britain and to limit its spread, if discovered. The fungus attacks the bark, girdles the tree with a typical canker and kills the part beyond the canker. Orange-yellow spore tendrils are produced in moist weather, and the fungus also produces mycelial fans under the bark. Chestnut blight can be distinguished from ink disease of the same tree in that the latter kills the tree completely, whereas the former often allows normal growth in the part below the canker. The Forestry Commission invites reports of suspected cases of the disease to its Research Station, Alice Holt Lodge, Farnham, Surrey. It is pointed out that material should be packed in a tin to avoid spreading fungus spores during transit.

\section{Animals of Scotland}

To accompany a new section devoted to animals of Scotland in the "Habitat Court" of the Glasgow Art Gallery and Museum, a suitable booklet has been prepared by the curator of the natural history department. This describes the appearance and habits of the twenty-eight mammals and birds included in the exhibit as well as their general taxonomic characters. Other exhibits are concerned with the animals of Africa, India and Australia, and the number of visitors they are attracting indicate their popularity. A fifth exhibit, featuring animals of arctic and antaretic regions, is under construction.

\section{Fear and Social Structure}

According to Dr. Grantly Dick Read, the influence of fear on social structure is not well understood or appreciated (South Afr. J. Sci., 47, No. 8; March 1951). Practically the whole basis of human communal existence to-day, he suggests, is influenced by fear; man's mental and physical health vary as to his ability to remain balanced in face of fear. Dr. Dick Read also suggests that children are not only emotionally influenced from the moment of their birth but even from the moment of conception. At fifteen weeks the reflexes of the foetus indicate individuality of behaviour. From birth the child is regularly subjected to stimuli which induce fear and lead to insecurity. According to its nature the child risks rebellion in violence or excessively anti-social behaviour, or resolves into that submissive state when even attempted activity of any sort, or any expression of its individuality, is paralysed by the deeply implanted fear of consequences. Dr. Dick Read believes that much of this unnecessary fear with its harmful effects on the individual and society would be eliminated if the fear of child-birth in women were eliminated.

\section{Montefiore Prizes for Electrical Development}

Montefrore Prizes, awarded by the George Montefiore Foundation of Liège, have been awarded to Dr. U. Krabbe (Fruens-Bage, Denmark), for an essay on "The Transductor Amplifier"; Dr. M. Hoyaux (Charleroi), for an essay on "Théorie de la chute dans l'are des redresseurs à vapeur de mercure"; E. H. Hubert (Liège), for an essay on "Contribution théorique et expérimentale aux possibilités d'application du réenclenchement automatique des disjoncteurs" ; and R. Pellisier (Paris), for an essay on "La propagation des ondes transitoires et périodiques le long des lignes électriques". These Prizes are usually given every five years; but the present awards are for the period 1939-50. They were established by a bequest of M. Montefiore, who founded the ElectroTechnical Institute of the University of Liège, and are given for original contributions of scientific or technical significance for electrical progress. The committee of award consists of five Belgian and five non-Belgian engineers. Seventeen essays were submitted on this occasion. Particulars relating to the awards can be obtained from the Fondation George Montefiore, Université, Liège ; the next awards will be made in 1955.

\section{Unification of the "Air Almanac" and the \\ "American Air Almanac"}

As from 1953, the "Air Almanac" and the "American Air Almanac" will become a single publication, under the title of the "Air Almanac". It will be produced jointly by H.M. Nautical Almanac Office of the Royal Greenwich Observatory, Herstmonceux, and the Nautical Almanac Office of the U.S. Naval Observatory in Washington, to meet the general requirements for air navigation in the United Kingdom, the United States and Canada. The "Air Almanac" will be printed and published separately in England and the United States, but will otherwise be identical. A number of changes have been necessary in both the former publications. None of these has any effect on the principles of tabulation or on the use of the "Almanac" in navigation.

\section{British Institution of Radio Engineers: Premiums for 1950}

THE British Institution of Radio Engineers has awarded the following Premiums for 1950, the awards being based on papers (titles as indicated) published during the year in the Journal of the Institution : Clerk Maxwell Premium (for the most outstanding paper of the year), to D. W. Heightman, English Electric Co., Ltd. (propagation of metric waves beyond the optical range); Heinrich Hertz Premium, R. Kompfner, Clarendon Laboratory, Oxford (operation of the travelling-wave tube at low level); Louis Sterling Premium, J. E. B. Jacob, Cinema Television, Ltd. (high-performance television monitors); Dr. Norman Partridge Memorial Award, S. W. Punnett, University College, Southampton (audio frequency selective amplifiers).

\section{Announcements}

Prof. EmILe GUYÉnOT, correspondant for the Section of Anatomy and Zoology of the Paris Academy of Sciences and professor of zoology and comparative anatomy in the University of Geneva, has been elected a non-resident member of the Academy in succession to the late Prof. L. Cuénot, formerly professor of zoology in the University of Nancy.

Prof. G. L. Brown, Jodrell professor of physiology in the University of London, and Sir James Learmonth, regius professor of clinical surgery and professor of surgery in the University of Edinburgh and surgeon to H.M. The King, have been appointed members of the Medical Research Council as from October 1.

TeE annual 'open day' at the Chemical Research Laboratory (Department of Scientific and Industrial Research), Teddington, will be on September 19 .

THE Medical Research Council announces that travelling awards in ophthalmology and otology under the Alexander Pigott Wernher Memorial Trust, tenable during the academic year 1951-52, have been made to Dr. Patricia R. Davey (Sydney) and Dr. R. N. Misra (Medical College, Lueknow). 